\title{
Physico-mechanical properties of tape and bulk samples of amorphous alloys based on $\mathrm{Fe}$
}

\author{
Lidia BOICHYSHYN ${ }^{1}$, Oksana HERTSYK ${ }^{1}$, Myroslava KOVBUZ ${ }^{1}$, Tetiana PEREVERZIEVA ${ }^{1}$ *, \\ Oleksandr RUDENKO ${ }^{2}$, Maksym NIZAMEIEV ${ }^{2}$ \\ ${ }^{1}$ Department of Physical and Colloid Chemistry, Ivan Franko National University of Lviv, \\ Kyryla i Mefodiya St. 6, UA-79005 Lviv, Ukraine \\ ${ }^{2}$ G.V. Kurdyumov Institute for Metal Physics, National Academy of Sciences of Ukraine, \\ Academician Vernadsky Blvd. 36, UA-03680 Kyiv, Ukraine \\ * Corresponding author. Tel: +38-032-260-03-97, e-mail: djunjer1@gmail.com
}

Received May 30, 2016; accepted June 29, 2016; available on-line November 7, 2016

The influence of the solidification rate of the melt was investigated for amorphous metallic systems based on iron: $\quad \mathrm{Fe}_{60} \mathrm{Co}_{7} \mathrm{Cr}_{4} \mathrm{~V}_{2} \mathrm{~W}_{1} \mathrm{Mo}_{1} \mathrm{Nb}_{1} \mathrm{~B}_{20} \mathrm{C}_{2} \mathrm{Si}_{2} \quad(\mathrm{HB}-4), \quad \mathrm{Fe}_{68} \mathrm{Mn}_{1} \mathrm{Mo}_{4} \mathrm{Cr}_{2} \mathrm{C}_{7} \mathrm{P}_{10} \mathrm{~B}_{5} \mathrm{Si}_{2} \mathrm{Cu}_{0.3} \mathrm{~W}_{0.3} \mathrm{Al}_{0.3} \quad$ (HBPC-4), $\mathrm{Fe}_{55} \mathrm{Ni}_{8} \mathrm{Co}_{6} \mathrm{Mo}_{4} \mathrm{Cr}_{2} \mathrm{~V}_{1} \mathrm{Al}_{2} \mathrm{P}_{9} \mathrm{C}_{6} \mathrm{~B}_{5} \mathrm{Si}_{2}$ (NHRP-6). Rapidly cooled $\left(10^{5} \mathrm{~K} \cdot \mathrm{s}^{-1}\right)$ alloys in the form of tapes with a thickness of $35 \mu \mathrm{m}$ showed lower microhardness and higher plasticity. The surface composition of bulk samples cooled at a rate of $10^{3} \mathrm{~K} \cdot \mathrm{s}^{-1}$ differed from that of tape samples, due to slow diffusion and formation of two or three phases. Some samples were enriched with $\mathrm{Cr}, \mathrm{V}, \mathrm{W}$, Mo, Nb, or Mn. Bulk alloys showed higher microhardness and lower plasticity than tape samples.

Amorphous alloys based on Fe / Bulk and tape samples / Microhardness / Plasticity / Elemental composition

\section{Фізико-механічні властивості стрічкових та об'ємних зразків аморфних сплавів на основі Fе}

\author{
Лідія БОЙЧИШИН ${ }^{1}$, Оксана ГЕРЦИК ${ }^{1}$, Мирослава КОВБУЗ ${ }^{1}$, Тетяна ПЕРЕВЕРЗСВА ${ }^{1}$, \\ Олександр РУДЕНКО², Максим НІЗАМЕСВ² \\ ${ }^{1}$ Кафедра фізичної та колоїдної хімії, Львівський начіональний університет імені Івана Франка, \\ вул. Кирила і Мефодія 6, 79005 Львів, Украӥна \\ ${ }^{2}$ Інститут металофізики ім. Г.В. Курдюмова НАН Украӥни, \\ бульв. Академіка Вернадського 36, 03680 ГСП Київ, Украӥна \\ * Контактна особа. Тел.: +38 032 2600397; e-mail: djunjerl@ gmail.com
}

Досліджено вплив швидкості гартування розплавів складнолегованих металевих систем на основі заліза: $\mathrm{Fe}_{60} \mathrm{Co}_{7} \mathrm{Cr}_{4} \mathrm{~V}_{2} \mathrm{~W}_{1} \mathrm{Mo}_{1} \mathrm{Nb}_{1} \mathrm{~B}_{20} \mathrm{C}_{2} \mathrm{Si}_{2} \quad(\mathrm{HB}-4), \quad \mathrm{Fe}_{68} \mathrm{Mn}_{1} \mathrm{Mo}_{4} \mathrm{Cr}_{2} \mathrm{C}_{7} \mathrm{P}_{10} \mathrm{~B}_{5} \mathrm{Si}_{2} \mathrm{Cu}_{0,3} \mathrm{~W}_{0,3} \mathrm{Al}_{0,3} \quad(\mathrm{HBPC}-4)$, $\mathrm{Fe}_{55} \mathrm{Ni}_{8} \mathrm{Co}_{6} \mathrm{Mo}_{4} \mathrm{Cr}_{2} \mathrm{~V}_{1} \mathrm{Al}_{2} \mathrm{P}_{9} \mathrm{C}_{6} \mathrm{~B}_{5} \mathrm{Si}_{2}$ (NHRP-6) на їхні фізико-механічні властивості. Швидкогартованим $\left(10^{5} K^{\cdot} \cdot \mathrm{c}^{-1}\right)$ сплавам у формі стрічки товщиною 35 мкм характерна нижча мікротвердість і дещо вища пластичність. Склад поверхні об'смних зразків, що формуються із швидкістю охолодження $10^{3} \mathrm{~K}^{-1}$, відрізнясться від стрічкових за рахунок тривалішої дифузії і формування 2-3 фаз. Деякі 3 них збагачені $\mathrm{Cr}$, V, W, Mo, Nb, Мn. Об’ємні сплави володіють вищою мікротвердістю, нижчою пластичністю в порівняні із стрічковими.

Аморфні сплави на основі заліза / Об'ємні та стрічкові зразки / Мікротвердість / Пластичність / Елементний склад 


\section{Вступ}

Аморфні металеві сплави (АМС) володіють високими механічними i магнітними властивостями [1-4]. Спеціальні легуючі додатки у певних співвідношеннях забезпечують антикорозійну тривкість та термостійкість [5,6].

Більшість АМС отримують шляхом миттевого охолодження 3 розплаву [7,8]. АМС у формі стрічки товщиною $30-50$ мкм формують із швидкістю охолодження $\left(10^{5}-10^{6}\right) \mathrm{K} \cdot \mathrm{c}^{-1}$. У зв'язку з технологією виливу на охолоджуючий елемент (мідний барабан) у випадку стрічкової форми AMC розрізняють контактну (к) поверхню, що безпосередньо контактує 3 охолоджуючим елементом, і зовнішню (з) поверхню. Незважаючи на невелику часову різницю охолодження $\left(10^{-5} \mathrm{c}^{-1}\right)$ між контактною і зовнішньою поверхнями, вони дещо відрізняються не тільки елементним складом [9], але i рівнем структурованості [10]. В залежності від швидкості обертання охолоджуючого мідного барабану отримували зразки АМС різної товщини. Швидкість гартування визначає структуру швидкогартованих стрічок в цілому [11]. Завдяки оптимізації елементного складу і співвідношення компонентів активізувався синтез об'ємних зразків АМС 3 достатньою в'язкістю вихідного розплаву, що дозволило отримувати їх при нижчих швидкостях охолодження $\left(10^{2}-10^{3}\right) \mathrm{K} \cdot \mathrm{c}^{-1}[12,13]$.

Синтез об'ємних аморфних матеріалів проводили цілеспрямовано, i вони зразу ж отримали широке застосування. Об'ємні аморфні сплави використовують як конструкційні матеріали, в оптичних пристроях, в якості матеріалів 3 високою корозійною тривкістю, електродних та магнітом'яких матеріалів і т.п. [14]. Поміж об'ємних аморфних систем особливої уваги заслуговують сплави на основі Fе через їхню комерційну важливість. Ферумвмісні об'ємні аморфні сплави представлені такими системами: $\mathrm{Fe}-(\mathrm{Al}, \mathrm{Ga})-(\mathrm{P}, \mathrm{C}, \mathrm{B}, \mathrm{Si}), \mathrm{Fe}-(\mathrm{Co}, \mathrm{Ni})-(\mathrm{Zr}, \mathrm{Nb}, \mathrm{Ta})-\mathrm{B}$, $\mathrm{Fe}-(\mathrm{Co}, \mathrm{Ni})-(\mathrm{Zr}, \mathrm{Nb}, \mathrm{Ta})-(\mathrm{Mo}, \mathrm{W})-\mathrm{B}, \mathrm{Fe}-\mathrm{C}-\mathrm{Si}-\mathrm{B}$ i $\mathrm{Fe}-\mathrm{Ni}-\mathrm{P}-\mathrm{B}$ [13]. Вони проявляють високу здатність до аморфізації, хороші магнітом'які та механічні властивості.
В цілому аморфні сплави, як магнітом'які матеріали, конкурують 3 феритами. Створена нова технологія металургійного виробництва стрічкових та об'ємних АМС безпосередньо 3 розплаву стимулювала розробку нового класу прецизійних матеріалів 3 унікальними фізикохімічними характеристиками, зокрема на основі заліза.

\section{Експериментальна частина}

Об'єктами нашого дослідження були три сплави: $\mathrm{Fe}_{60} \mathrm{Co}_{7} \mathrm{Cr}_{4} \mathrm{~V}_{2} \mathrm{~W}_{1} \mathrm{Mo}_{1} \mathrm{Nb}_{1} \mathrm{~B}_{20} \mathrm{C}_{2} \mathrm{Si}_{2} \quad$ (HB-4), $\mathrm{Fe}_{68} \mathrm{Mn}_{1} \mathrm{Mo}_{4} \mathrm{Cr}_{2} \mathrm{C}_{7} \mathrm{P}_{10} \mathrm{~B}_{5} \mathrm{Si}_{2} \mathrm{Cu}_{0,3} \mathrm{~W}_{0,3} \mathrm{Al}_{0,3} \quad$ (HBPC-4), $\mathrm{Fe}_{55} \mathrm{Ni}_{8} \mathrm{Co}_{6} \mathrm{Mo}_{4} \mathrm{Cr}_{2} \mathrm{~V}_{1} \mathrm{Al}_{2} \mathrm{P}_{9} \mathrm{C}_{6} \mathrm{~B}_{5} \mathrm{Si}_{2}$ (NHRP-6) y формі стрічок та об'ємних пластинок. Розміри стрічки: ширина $\sim 20$ мм, товщина $\sim 35$ мкм; пластинки: ширина $\sim 10$ мм, товщина $\sim 1$ мм. Зразки АМС виготовлені і передані для дослідження 3 Інституту металофізики ім. Г.В. Курдюмова НАН України, м. Київ. Різні температурні режими формування стрічки та об'ємних зразків АMC зумовлюють різницю компонентного складу, який перед дослідженням уточнювали за допомогою енергодисперсійного мікроаналізу 3 використанням скануючого електронного мікроскопу РЕММА-102-02.

Уточнений елементний склад наведений в Табл. 1. Простежується суттєва різниця між усередненим елементним складом вихідної шихти i поверхнями готових виробів АМС. Поверхнева концентрація елементів залежить від енергії активації дифузії атомів від і до поверхні в процесі гартування розплаву.

Рентгеноструктурний аналіз АМС проводили 3 використанням дифрактометра DRON-3M, Cu $K_{\alpha^{-}}$ випромінювання. Рівень структурної впорядкованості об'ємних зразків вищий від стрічкових зразків (Рис. 1). Повільніша швидкість гартування викликає часткову нанокристалізацію об'ємного зразка. На фоні аморфного гало 3'являються піки при кутах $2 \theta=52^{\circ} ; 76^{\circ} ; 102^{\circ}$ (Рис. 1, крива 2), які відповідають появі нанокристалічного $\alpha$-Fe [15].

Таблиця 1 Вихідний та уточнений елементний склад поверхні зразків АМС різної форми (ат. \%).

\begin{tabular}{|c|c|c|c|c|c|c|c|c|c|c|c|c|c|}
\hline Елемент & $\mathrm{Fe}$ & Co & $\mathrm{Cr}$ & $\mathrm{V}$ & $\mathrm{W}$ & Mo & $\mathrm{Nb}$ & $\mathrm{Mn}$ & $\mathrm{Al}$ & $\mathrm{Ni}$ & $\mathrm{Cu}$ & $\mathrm{P}$ & $\mathrm{Si}$ \\
\hline \multicolumn{14}{|c|}{ HB-4 $\mathrm{Fe}_{60} \mathrm{Co}_{7} \mathrm{Cr}_{4} \mathrm{~V}_{2} \mathrm{~W}_{1} \mathrm{Mo}_{1} \mathrm{Nb}_{1} \mathrm{~B}_{20} \mathrm{C}_{2} \mathrm{Si}_{2} *$} \\
\hline Пластинка & 77,08 & 11,2 & 4,93 & 0,69 & 1,86 & 3,45 & 0,55 & - & - & - & - & - & - \\
\hline Стрічка & 72,26 & 8,97 & 7,17 & 1,20 & 1,44 & 2,38 & 0,96 & - & - & - & - & - & - \\
\hline \multicolumn{14}{|c|}{ HBPC-4 Fe ${ }_{68} \mathrm{Mn}_{1} \mathrm{Mo}_{4} \mathrm{Cr}_{2} \mathrm{C}_{7} \mathrm{P}_{10} \mathrm{~B}_{5} \mathrm{Si}_{2} \mathrm{Cu}_{0,3} \mathrm{~W}_{0,3} \mathrm{Al}_{0,3} *$} \\
\hline Пластинка & 74,27 & - & 2,60 & - & 0,10 & 4,08 & - & 1,71 & 0,78 & - & 0,25 & 12,9 & 1,41 \\
\hline Стрічка & 75,15 & - & 2,74 & - & 0,03 & 5,10 & - & 1,67 & 0,60 & - & 0,13 & 9,33 & 2,75 \\
\hline \multicolumn{14}{|c|}{ NHRP-6 $\mathrm{Fe}_{55} \mathrm{Ni}_{8} \mathrm{Co}_{6} \mathrm{Mo}_{4} \mathrm{Cr}_{2} \mathrm{~V}_{1} \mathrm{Al}_{2} \mathrm{P}_{9} \mathrm{C}_{6} \mathrm{~B}_{5} \mathrm{Si}_{2} *$} \\
\hline Пластинка & 60,25 & 7,00 & - & 0,46 & 2,46 & 5,44 & - & - & 1,09 & 8,55 & - & 9,17 & 2,73 \\
\hline Стрічка & 58,65 & 6,48 & - & 1,01 & 2,61 & 6,25 & - & - & 1,26 & 8,45 & - & 8,51 & 2,74 \\
\hline
\end{tabular}


Зовнішня поверхня стрічки при гартуванні зі швидкістю $10^{5} \mathrm{~K} \cdot \mathrm{c}^{-1} \epsilon$ гладкою і однорідною, без дефектів і включень, а при знижені швидкості до $10^{3} \mathrm{~K} \cdot \mathrm{c}^{-1}$ у випадку гартування об' ємних зразків чітко простежується неоднорідність їхньої поверхні (Рис. 2).

На мікрофотографії на Рис. 2,a, окрім однорідної поверхні, як і на мікрофотографії на Рис. 2,б, відображається ще і рельєф охолоджуючого мідного барабана, який безпосередньо стикається 3 розплавом. На Рис. 2,в простежуються значно більші елементи поверхневих шарів, які, очевидно, формуються під час повільнішого гартування розплаву $[16,17]$.

Оцінка мікротвердості стрічкових та об'ємних зразків багатокомпонентних аморфних сплавів показала, що менша швидкість гартування 3 розплаву у випадку об'ємних брусків підвищує їхню мікротвердість (Табл. 2).

Для визначення мікротвердості за Вікерсом застосували прилад ПМТ-3. Алмазну пірамідку під дією вантажу втискували у досліджуваний зразок. Діагональ утвореного відбитку вимірювали окулярним мікрометром. Число твердості $H_{v}$ обчислювали за формулою [18,19]:

$$
H_{v}=1854 \times P / d^{2},\left[\mathrm{H}_{0}\right]=\left[\kappa \Gamma / \mathrm{MM}^{2}\right],
$$

де $P=165$ - вага навантаження, г; $d$ - діагональ відбитка, мкм.

Сучасні методи різки, шліфування i полірування зразків забезпечили високу якість металографічних шліфів.

Пластичність зразків $(\delta)$ оцінена за одержаними значеннями $H_{v}$ :

$$
\delta=1-14.3 \times\left(1-v-2 v^{2}\right) H_{v} / E,
$$

де $H_{v}$ - твердість за Вікерсом; $v$ - коефіцієнт Пуассона; $E$ - модуль Юнга.

Збільшення різниці мікротвердості стрічки $\mathrm{i}$ пластинки в ряді $\Delta H(\mathrm{HB}-4)<\Delta H(\mathrm{HBPC}-4)<$ $\Delta H$ (NHRP-6) свідчить про утворення міцніших поверхневих шарів об'ємних зразків. В умовах повільнішого охолодження вища ймовірність дифузії до поверхні атомів $\mathrm{B}, \mathrm{Si}$. Відношення $H_{v} / E$ для більшості металів не перевищує 0,02 , але у багатокомпонентних аморфних сплавах ці значення коливаються в межах 0,06-0,08 і мають лінійну залежність характеристики пластичності $\delta=\mathrm{f}\left(H_{v} / E\right)$ від відношення мікротвердості $\left(H_{v}\right)$ до модуля Юнга $(E)$ (Рис. 3). Найбільша різниця пластичності стрічки і об'ємного зразка простежується у NHRP-6, значно менша - у HB-4 та HBPC-4.

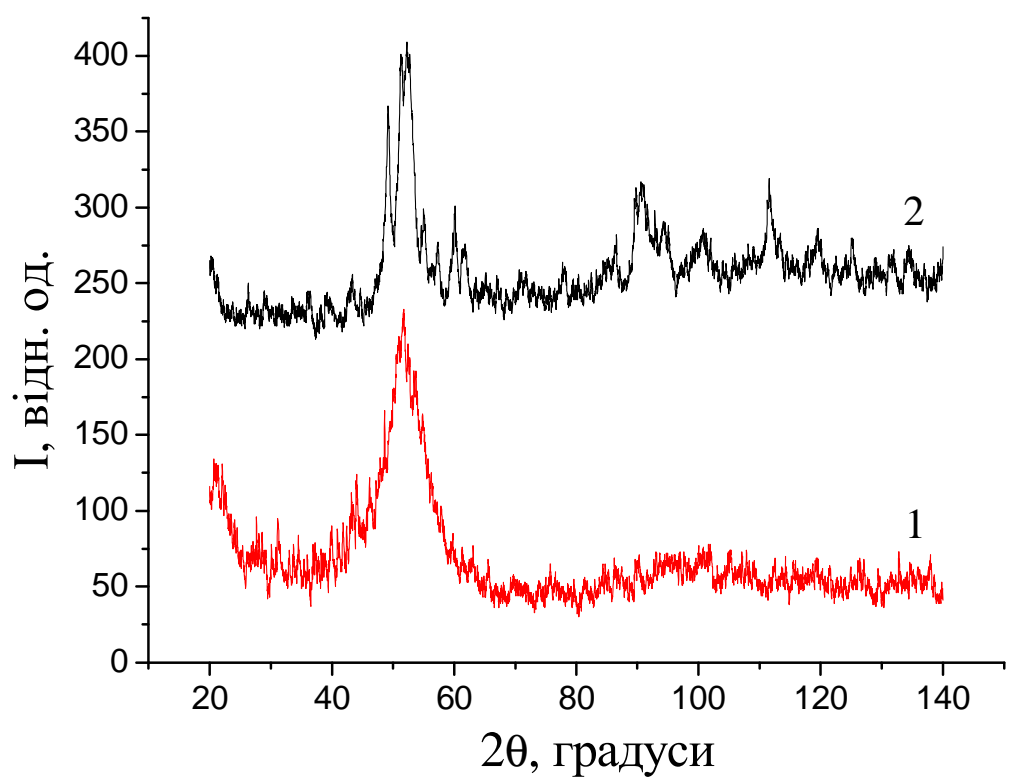

Рис. 1 Дифрактограми стрічкового (1) та об'ємного (2) зразків NHRP-6.

Таблиця 2 Механічні характеристики зразків АМС різної форми.

\begin{tabular}{c|c|c|c|c|c|c|c}
\hline Матеріал & Форма & $H_{v}, \Gamma П а$ & $\Delta H^{*}, \Gamma \Pi а$ & $E, \Gamma \Pi а$ & $H_{v} / E$ & $v$ & $\delta$ \\
\hline \multirow{2}{*}{ HВ-4 } & стрічка & 12,1 & \multirow{2}{*}{1,00} & 147 & 0,082 & 0,3 & 0,39 \\
& пластинка & 13,1 & & 150 & 0,087 & 0,3 & 0,35 \\
\hline \multirow{2}{*}{ HВРС-4 } & стрічка & 9,56 & \multirow{2}{*}{2,64} & 137 & 0,070 & 0,3 & 0,48 \\
& пластинка & 11,2 & & 152 & 0,074 & 0,3 & 0,45 \\
\hline \multirow{2}{*}{ NHRP-6 } & стрічка & \multirow{2}{*}{9,44} & \multirow{2}{*}{4,16} & 148 & 0,064 & 0,3 & 0,52 \\
& пластинка & 13,6 & & 158 & 0,086 & 0,3 & 0,37 \\
\hline
\end{tabular}

$\Delta H^{*}=H_{\text {пластинка }}-H_{\text {стрічка }}$ 
L. Boichyshyn et al., Physico-mechanical properties of tape and bulk samples of amorphous alloys based on Fe
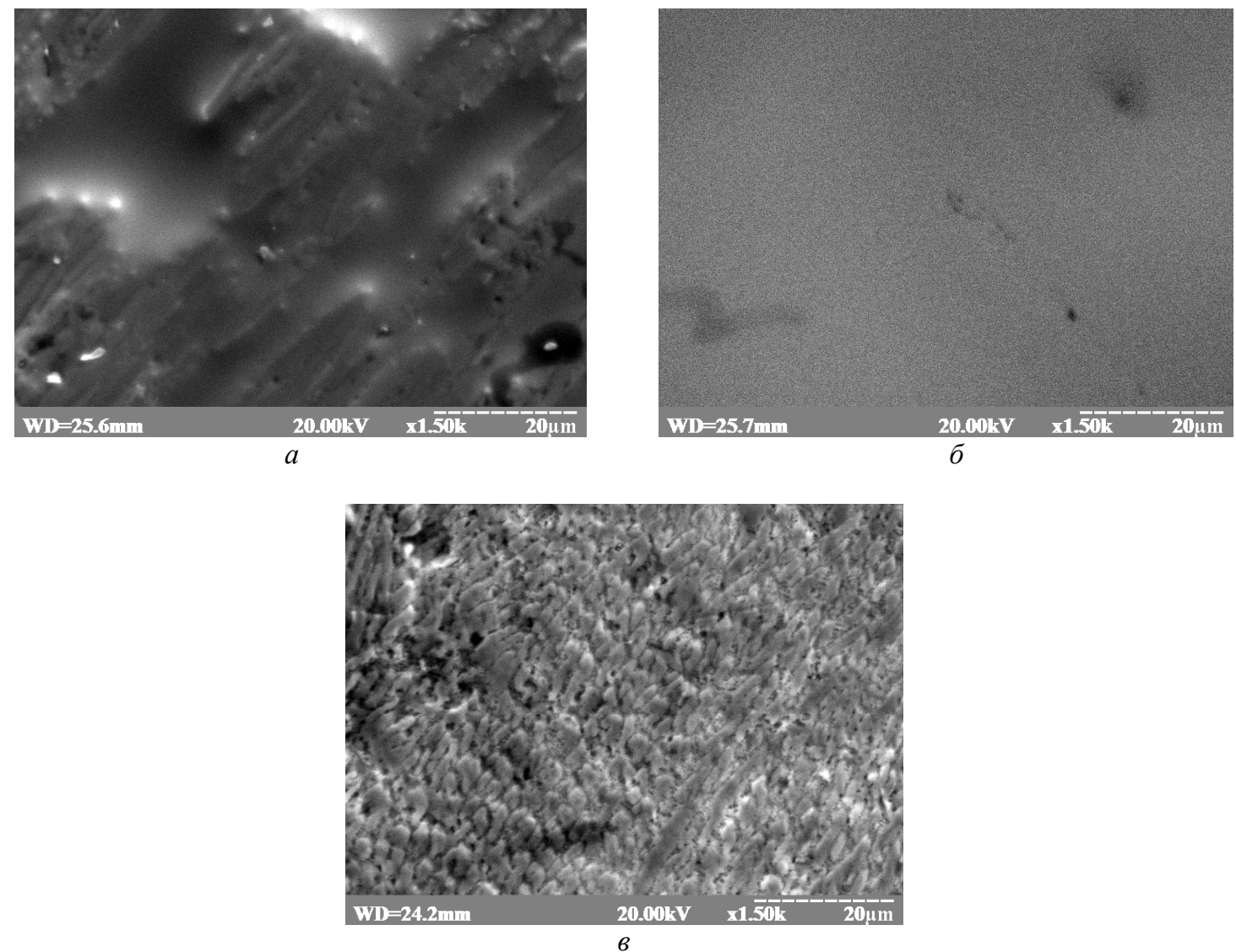

Рис. 2 Мікрофотографії контактного (a), зовнішнього (б) боків стрічки та об’ємного (в) AМС HВРС-4.

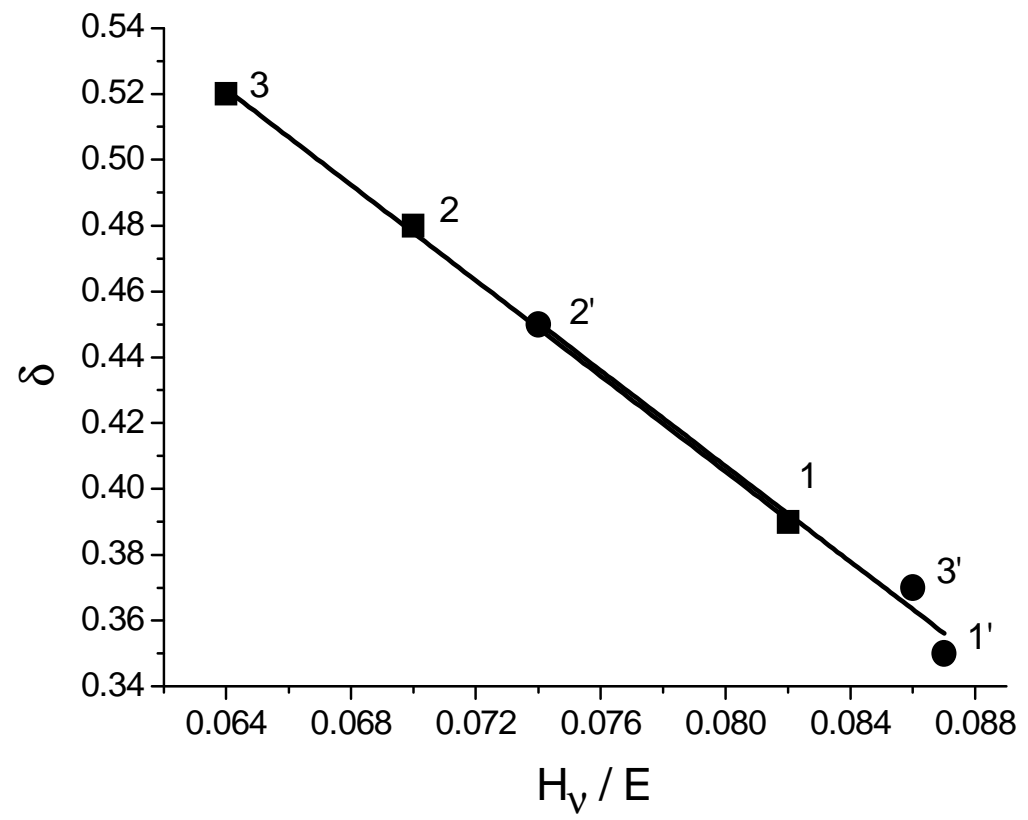

Рис. 3 Залежність характеристики $\delta$ від відношення $H_{v} / E$ AMC HB-4 $\left(1,1^{\prime}\right)$; HBPC-4 $\left(2,2^{\prime}\right)$; NHRP-6 $\left(3,3^{\prime}\right)$ різної форми: стрічка $-1,2,3$; пластинка $-1 ', 2$ ', $3^{\prime}$.

Необхідно відмітити, що поверхнева концентрація $\mathrm{Si}$ у світлій фазі сплаву (Табл. 3) сприяє підвищенню мікротвердості. При ідентуванні вже при кімнатній температурі відбувається фазовий перехід. Твердість цього матеріалу визначається тиском фазового переходу, а не порогом текучості [20]. 
Як видно 3 мікрофотографій на Рис. 4 елементний склад поверхні визначає їі морфологію. На мікрофотографіях НB-4, NHRP-6 можна виділити за інтенсивністю забарвлення три зони, а у випадку НВ-4 - дві.

Елементний склад виділених областей поданий в Табл. 3. Порівняння інтенсивності забарвлення свідчить про нерівномірний розподіл металевих компонентів, в основному, Fe. Оксиди Мо концентруються у світлій фазі.

\section{Висновки}

На основі дифрактометричних досліджень показано, що в об'ємних зразках у порівнянні із стрічковими, які застигають із вищою на два порядки швидкістю охолодження, в аморфній матриці з'являється нанокристалічний $\alpha-\mathrm{Fe}$.

Об'ємні зразки характеризуються вищою мікротвердістю $\left(H_{v}\right)$ і нижчою пластичністю $(\delta)$ в порівнянні 3 стрічковими зразками однакового вихідного складу. Найбільша різниця між значеннями пластичності стрічкового та об'ємного зразків простежується у випадку сплаву NHRP-6 $(\Delta \delta=0,15)$. У двох інших сплавів різниця між значеннями пластичності у 4-5 разів менша і $\epsilon$ близькою $(\Delta \delta=0,03 ; 0,04)$.

Відхилення від лінійної залежності $\delta=\mathrm{f}\left(H_{v} / E\right)$ сплаву NHRP-6 ( $\left.\mathrm{Fe}_{55} \mathrm{Ni}_{8} \mathrm{Co}_{6} \mathrm{Mo}_{4} \mathrm{Cr}_{2} \mathrm{~V}_{1} \mathrm{Al}_{2} \mathrm{P}_{9} \mathrm{C}_{6} \mathrm{~B}_{5} \mathrm{Si}_{2}\right)$ може бути викликане збільшенням вмісту кремнію та фосфору на поверхні об'ємного зразка, що приводить до фазових перетворень під навантаженням під час вимірювання мікротвердості $\left(H_{v}\right)$.

\section{Подяка}

Робота виконана згідно 3 науковим проектом Міністерства освіти на науки України “Об'ємні та стрічкові аморфні сплави на основі заліза, леговані $d$-елементами, як основа нових матеріалів" (державний реєстраційний номер 0115U003263).
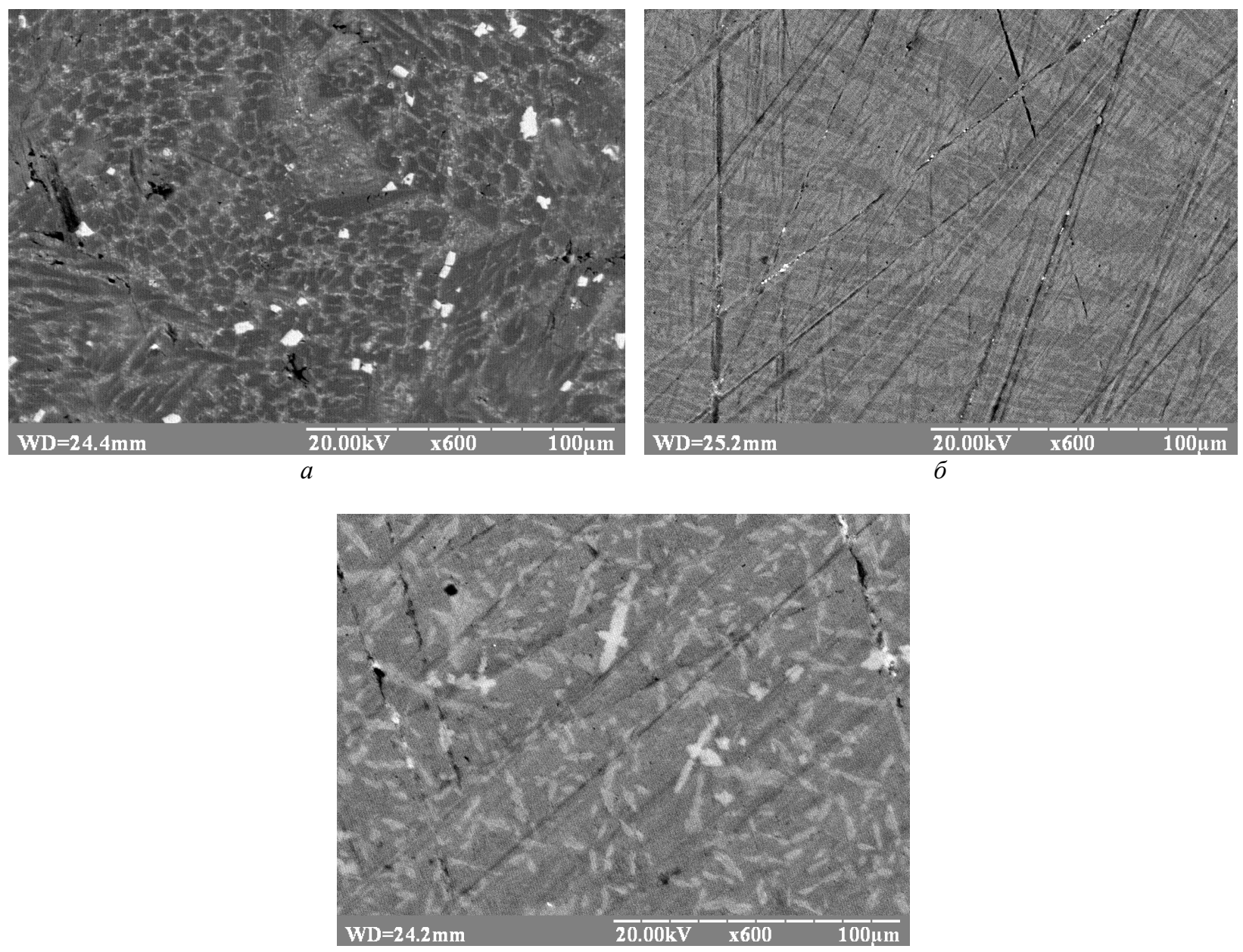

B

Рис. 4 Мікрофотографії поверхні об’ємних сплавів HB-4 (a), HBPC-4 (б), NHRP-6 (в). Визначено склад трьох умовних областей: темної, сірої, світлої. 
L. Boichyshyn et al., Physico-mechanical properties of tape and bulk samples of amorphous alloys based on Fe

Табл. 3 Вміст хімічних елементів фазових областей на поверхні об’ємних аморфних зразків (ат. \%).

\begin{tabular}{|c|c|c|c|c|c|c|c|c|c|c|c|c|c|}
\hline \multirow{2}{*}{ Зразок } & \multirow{2}{*}{ Фаза } & \multicolumn{12}{|c|}{ Елемент } \\
\hline & & $\mathrm{Fe}$ & $\mathrm{Co}$ & $\mathrm{Cr}$ & $\mathrm{V}$ & $\mathrm{W}$ & Mo & $\mathrm{Mn}$ & $\mathrm{Nb}$ & $\mathrm{Al}$ & $\mathrm{Ni}$ & $\mathrm{P}$ & $\mathrm{Si}$ \\
\hline \multirow{3}{*}{ HB-4 } & Темна & 77,91 & 6,61 & 11,2 & 1,76 & 0,99 & 1,48 & - & 0,00 & - & - & - & - \\
\hline & Cipa & 76,27 & 12,2 & 4,84 & 0,96 & 1,99 & 3,28 & - & 0,42 & - & - & - & - \\
\hline & Світла & 33,10 & 4,71 & 12,7 & 7,68 & 15,4 & 18,1 & - & 8,32 & - & - & - & - \\
\hline \multirow{2}{*}{ HBPC-4 } & Темна & 74,13 & - & 3,14 & - & - & 3,06 & 1,44 & - & - & - & 17,1 & 1,13 \\
\hline & Cipa & 74,36 & - & 5,96 & - & - & 11,2 & 2,92 & - & - & - & 1,87 & 3,69 \\
\hline \multirow{3}{*}{ NHRP-6 } & Темна & 66,94 & 7,82 & 2,52 & 0,63 & - & 3,44 & - & - & 1,01 & 9,28 & 6,30 & 2,06 \\
\hline & Cipa & 37,55 & 8,19 & 5,14 & 2,05 & - & 17,9 & - & - & 0,94 & 5,47 & 21,2 & 1,44 \\
\hline & Світла & 32,95 & 6,92 & 6,26 & 2,80 & - & 27,9 & - & - & 0,61 & 10,9 & 4,30 & 7,23 \\
\hline
\end{tabular}

\section{Літературні посилання}

[1] W.H. Wang, C. Dong, C.H. Shek, Mater. Sci. Eng., $R 44$ (2004) 45-89.

[2] M.E. McHenry, M.A. Willard, D.E. Laughlin, Prog. Mater. Sci. 44 (1999) 291-443.

[3] А.П. Семин, Автореф. ... дисс. канд. техн. наук: 01.04.07, Сибирский гос. индустр. унив., 2004, $19 \mathrm{c}$.

[4] N. Mariano, C. Souza, J. May, S. Kuri, Mater. Sci. Eng. 90 (2002) 1-6.

[5] P.F. Gostin, A. Gebert, L. Schultz, Corros. Sci. 52 (2010) 273-281.

[6] A.P. Shpak, V.N. Varyukhin, V.I. Tkatch, V.V. Maslov, Y.Y. Beygelzimer, S.G. Synkov, V.K. Nosenko, S.G. Rassolov, Mater. Sci. Eng., A 425 (2006) 172-177.

[7] М.Р. Филонов, Ю.А. Аникин, Ю.Б. Левин, Теоретические основы производства аморфных и нанокристаллических сплавов методом сверхбыстрой закалки, МИСиС, Москва, 2006, 326 с.

[8] А.Ю. Коротченко, С. Поляков, Ю. Баст, Ю.О. Фокин, Л.В. Пастухов, Литейное производство 1 (2013) 31-36.

[9] О.М. Герцик, М.О. Ковбуз, О.А. Єзерська, Т.Г. Переверзєва, Л.М. Беднарська, Фіз. хім. тв. тіла 12 (2011) 618-624.
[10] G. Abrosimova, A.S. Aronin, Yu.V. Kir'janov, D.V. Matveev, V.V. Molokanov, I.I. Zver'kova, J. Non-Cryst. Solids 288 (2001) 121-126.

[11] А.М. Бовда, А.Е. Дмитренко, С.В. Малыхин, Л.В. Онищенко, В.Н. Пелых, Bопросы атомной науки и техники, сер. вакуум, чистые материаль, сверхпроводники 4(16) (2007) 173-178.

[12] С.В. Губарєв, Автореф. дис. ... канд. техн. наук: 05.16.02, Дніпродзержин. держ. техн. унів., 2014, 24 c.

[13] C. Zhu, Q. Wang, J. Zhang, Y. Wang, C. Dong, Int. J. Miner., Metall. Mater. 17 (2010) 323-326.

[14] A. Inoue, Acta Mater. 48 (1) (2000) P. 279-306.

[15] L. Bednarska, S. Mudry, M. Kovbuz, B. Kotur, O. Hertsyk, G. Heneczok, M. Karolus, J. NonCryst. Solids 354 (2008) 4359-4362.

[16] Л.Н. Ларионов, Металлофиз. новейшие технологи 11 (1995) 69-72.

[17] M.A. Munoz-Morris, S. Surinach, M. Gich, M.D. Baró, D.G. Morris, Acta Mater. 51 (2003) 1067-1077.

[18] Yu.V. Milman, J. Phys. D: Appl. Phys. 41 (2008) 074013.

[19] Yu.V. Milman, S. Dub, A. Golubenko, Mater. Res. Soc. Symp. Proc. 1049 (2008) 123-128.

[20] V. Gridneva, Yu.V. Milman, V.I. Trefilov, Phys. Status Solidi A 14 (1) (1972) 177-182. 